\title{
Street-level bureaucracy en verwijzingen naar gedragsinterventies in Nederlandse penitentiaire inrichtingen
}

\author{
Discrepanties tussen beleid en praktijk
}

Anouk Bosma, Maarten Kunst, Anja Dirkzwager \& Paul Nieuwbeerta

Studies toonden aan dat gedetineerden niet altijd volgens de daarvoor geldende richtlijnen naar behandelprogramma's worden verwezen. Street-level bureaucracy theory suggereert dat dit komt doordat overheidsmedewerkers beleid niet altijd uitvoeren zoals dit is voorgeschreven. Deze studie onderzocht of dit ook het geval is bij het verwijzen van gedetineerden naar gedragsinterventies in Nederlandse penitentiaire inrichtingen, en onderzocht welke factoren daarmee samenhingen. Dit werd onderzocht onder een groep van 541 mannelijke gedetineerden die deelnamen aan het programma Terugdringen Recidive. De resultaten wezen uit dat officiële beleidsrichtlijnen veelal niet leidend waren bij het verwijzen van gedetineerden naar gedragsinterventies. In plaats daarvan was het brede scala aan risicofactoren van invloed op behandelverwijzingen, en werden gedetineerden vaker naar programma's verwezen als zij een langere gevangenisstraf hadden opgelegd gekregen.

\section{Introductie}

Elk jaar keert een aanzienlijk aantal ex-gedetineerden terug in de maatschappij. Uit onderzoek blijkt dat veel ex-gedetineerden te maken hebben met lichamelijke en psychiatrische problemen, verslavingsproblematiek, werkloosheid, dakloosheid en financiële problemen (Dirkzwager e.a., 2009). De recidive onder ex-gedetineerden is hoog. Binnen zes jaar na vrijlating is meer dan 70 procent opnieuw veroordeeld en bijna 50 procent opnieuw opgesloten (Wartna e.a., 2010). In veel westerse landen werden daarom gedragsinterventies geïmplementeerd gericht op het voorkomen van recidive onder ex-gedetineerden (Hannah-Moffat, 2005). Onderzoek heeft aangetoond dat dergelijke programma's effectief kunnen zijn (Andrews e.a., 1990; Gendreau, 1996; Gendreau, e.a., 1996), mits zij aan een aantal voorwaarden voldoen. Volgens het risk-need-responsivity (RNR)-model (Andrews e.a., 1990) moeten gedragsinterventies gericht zijn op delinquenten met een hoog risico op recidive (risk), en op het verminderen van kenmerken die samenhangen met toekomstig crimineel gedrag, oftewel criminogene factoren (need). Ten slotte dienen programma's aangeboden te worden op een manier die aansluit bij de kenmerken van de individuele delinquent (responsivity; Andrews \& Bonta, 2010).

In Nederland wordt al geruime tijd gewerkt met gedragsinterventies die zijn gebaseerd op het RNR-model, eerst onder de noemer van het programma Terugdrin- 
gen Recidive (TR), dat landelijk werd ingevoerd in 2007, en sinds 2014 in het kader van het plusprogramma. In detentie wordt een viertal typen gedragsinterventies aangeboden, namelijk: cognitieve vaardigheidstraining (CoVa), leefstijltraining (gericht op drank- en/of drugsgebruik of gokgedrag), arbeidsvaardighedentraining en agressieregulatietraining. Overigens moet opgemerkt worden dat alleen de CoVa-training en leefstijltraining met enige regelmaat worden toegepast (Bosma e.a., 2013).

Speciaal daarvoor geselecteerde en getrainde gevangenismedewerkers zijn, in samenwerking met en veelal na advies van de reclassering, verantwoordelijk voor het verwijzen van gedetineerden naar deze behandelprogramma's, en het toezicht houden op de uitvoering ervan. Deze medewerkers werden ten tijde van het programma TR trajectbegeleiders genoemd (GW \& 3RO, 2007), en zijn nu casemanager geworden (Inspectie Veiligheid en Justitie, 2016). ${ }^{1}$

De juiste toewijzing van delinquenten aan behandelprogramma's, dat wil zeggen passend bij hun individuele problematiek, is een belangrijke voorwaarde voor het effectief behandelen van gedetineerden. Zoals in de medische wereld, waar een arts eerst de aard en ernst van klachten moet inschatten, alvorens een behandeling te kunnen indiceren, leunen effectieve justitiële behandelingen op een juiste inschatting van het risico op recidive en criminogene factoren die moeten worden aangepakt om dit risico te verminderen (Latessa e.a., 2002).

Om het recidiverisico en de criminogene behoeften van gedetineerden in te kunnen schatten, wordt in Nederland gebruik gemaakt van de RISc (Recidive Inschattingsschalen). Dit is een risicotaxatie-instrument dat is gebaseerd op het Engelstalige Offender Assessment System (OASys; Howard e.a., 2003). Met de RISc wordt het risico op recidive bepaald, worden criminogene factoren op een twaalftal domeinen ingeschat (te weten: delictgeschiedenis, huidig delict en delictpatroon; huisvesting en wonen; opleiding, werk en leren; inkomen en omgaan met geld; relaties met partner, gezin en familie; relaties met vrienden en kennissen; drugsgebruik; alcoholgebruik; emotioneel welzijn; denkpatronen, gedrag en vaardigheden; en houding), wordt de mate van responsiviteit voor behandeling bepaald (zoals motivatie), en wordt nagegaan of verdere diagnostiek wenselijk is (Adviesbureau Van Montfoort \& Reclassering Nederland, 2004; Van der Knaap e.a., 2012).

Beleidsrichtlijnen bepalen dat de RISc leidend moet zijn bij het verwijzen van delinquenten naar behandelprogramma's. Zo komen gedetineerden bijvoorbeeld in aanmerking voor deelname aan CoVa-training als zij een matig tot hoog recidiverisico hebben en er sprake is van cognitieve tekorten, aangetoond met de RIScschaal denkpatronen, gedrag en vaardigheden (Ministerie van Justitie, 2007).

Eerder onderzoek (zie Bosma e.a., 2013) toonde aan dat gedragsinterventies in Nederlandse penitentiaire inrichtingen (hierna: PI's) slechts op beperkte schaal werden toegepast. Zo werd geconcludeerd dat ten tijde van het programma TR hooguit 35 procent van de participanten deelnam aan een gedragsinterventie (Bosma e.a., 2013). Terwijl een andere studie aantoonde dat er bij bijna iedere

1 In de huidige bijdrage is gekozen voor de term trajectbegeleider, omdat de geanalyseerde data voornamelijk gaan over de periode waarin zij nog geen casemanager genoemd werden. 
gedetineerde voldoende criminogene factoren aanwezig waren om voor een gedragsinterventie in aanmerking te komen (Fischer e.a., 2012). Dit suggereert dat gedetineerden niet naar programma's verwezen worden op basis van RISc-uitkomsten, wat ook zou betekenen dat verwijzingen naar gedragsinterventies niet volgens de geldende beleidsregels worden gemaakt. Er is echter nooit eerder onderzocht of dit het geval is. Deze studie tracht dit in kaart te brengen.

\section{Theoretisch kader}

Verschillende factoren kunnen ervoor zorgen dat overheidsbeleid niet wordt uitgevoerd zoals het in beleidsrichtlijnen is voorgeschreven. Lipsky (1980) stelt met zijn street-level bureaucracy theory (hierna: SLBT) dat een succesvolle tenuitvoerlegging van beleid voor een groot deel afhankelijk is van het handelen van streetlevel bureaucrats, of frontlijnwerkers: overheidsmedewerkers met een relatief lage hiërarchische positie, zoals leerkrachten en politieagenten, die in direct contact staan met burgers en bij de uitvoering van hun taken een zekere mate van discretionaire bevoegdheid kunnen uitoefenen (Lipsky, 1980). Deze discretionaire bevoegdheid hebben zij omdat ze complexe beslissingen moeten maken waarbij zij algemene beleidsregels moeten interpreteren en toepassen in specifieke situaties (Lipsky, 1980; 2010). Frontlijnwerkers hebben bij het uitvoeren van hun taken daarnaast een grote mate van autonomie (denk bijvoorbeeld aan een politieagent, die zelfstandig burgers mag aanhouden).

Het werk van frontlijnwerkers kan moeilijk en veeleisend zijn; zij functioneren veelal onder grote tijdsdruk, met beperkte middelen. Om hun werk zo efficiënt mogelijk te kunnen doen, zo beredeneert Lipsky (1980), hanteren zij copingstrategieën, zoals het groeperen van cliënten (op basis van stereotypen), waarop routinematige beslissingen kunnen worden toegepast (routinizing), of het herdefinieren van taken en prioriteiten, waarbij veelal voorrang wordt gegeven aan gemakkelijke cliënten (creaming; Ellis, 2011; Fineman, 1998; Lehmann Nielsen, 2006; Lipsky, 1980; 2010; Tummers e.a., 2015). Coping heeft vaak als gevolg dat frontlijnwerkers afwijken van voorgeschreven regels, wat de implementatie van beleid negatief kan beïnvloeden (Winter, 2002).

Hoewel in eerdere studies wellicht nooit eerder als zodanig aangewezen, kunnen trajectbegeleiders beschouwd worden als frontlijnwerkers. Zij zijn overheidspersoneel met een executieve functie, staan in direct contact met en nemen zelfstandig beslissingen over burgers (gedetineerden), waarbij zij een zekere mate van discretionaire ruimte hebben. Zoals het geval is bij andere frontlijnwerkers is hun werklast hoog, zo hebben zij bijvoorbeeld veelal een te grote caseload om iedere gedetineerde te kunnen begeleiden (IST, 2010). Als zijnde frontlijnwerkers wordt verwacht dat trajectbegeleiders, als gevolg van een kloof tussen middelen en verwachtingen, en als resultaat van verschillende copingmechanismen, gebruik maken van hun discretionaire bevoegdheid en relatieve autonomie, wat naar verwachting zal resulteren in behandelverwijzingen die niet volledig in lijn zijn met beleidsrichtlijnen. 
Daarnaast wordt verwacht dat een aantal specifieke kenmerken daarop van invloed zal zijn. In navolging van SLBT wordt verwacht dat trajectbegeleiders veelal zullen vervallen in gestandaardiseerde verwijzingen van gedetineerden naar programma's, waarbij prioriteit gegeven wordt aan minder problematische gedetineerden, die naar verwachting succesvol aan programma's zullen deelnemen (creaming). Trajectbegeleiders hebben bij het verwijzen van gedetineerden naar behandelprogramma's geen toegang tot diepgaande informatie met betrekking tot, bijvoorbeeld, gerechtelijke documentatie over elk aspect van hun huidige delict (IST, 2010). In plaats daarvan moeten zij het doen met RISc-uitkomsten. Verwacht wordt dat trajectbegeleiders zich bij het verwijzen van gedetineerden naar programma's niet alleen laten leiden door een aangewezen aantal risicoschalen, maar zich ook baseren op het totaal van risicodomeinen dat met de RISc in kaart wordt gebracht, waarbij meer (ernstige) risicofactoren zullen leiden tot minder verwijzingen.

Ten slotte wordt verwacht dat een grotere kloof tussen de eerdergenoemde middelen en verwachtingen de discrepantie tussen voorgeschreven en uitgevoerd beleid vergroot. We verwachten daarbij dat een aantal specifieke organisatorische omstandigheden behandelverwijzingen zullen beïnvloeden, waarbij meer optimale omstandigheden zullen resulteren in meer verwijzingen. Zo wordt verondersteld dat strafduur een positieve invloed zal hebben op het aantal verwijzingen naar behandelprogramma's. Daarnaast wordt verwacht dat de bezettingsgraad van een PI en de trajectbegeleider/gedetineerde-ratio de verwijzingen naar behandelprogramma's beïnvloeden. Waarbij wordt verondersteld dat overbezetting en een tekort aan staf een negatieve invloed hebben op de mate waarin gedetineerden naar programma's worden verwezen. Tot slot, niet elk behandelprogramma wordt aangeboden in elke PI, en verwijzing naar een gedragsinterventie betekent in sommige gevallen dat een gedetineerde moet worden overgeplaatst naar een andere PI. De verwachting is dat de inhouse beschikbaarheid van een gedragsinterventie behandelverwijzingen positief zal beïnvloeden.

\section{Eerder onderzoek}

Op basis van SLBT wordt in deze studie verwacht dat trajectbegeleiders, als zijnde frontlijnwerkers, zullen afwijken van geldende beleidsrichtlijnen. Eerder onderzoek heeft zich helaas nooit specifiek gericht op trajectbegeleiders (of ander gevangenispersoneel belast met het verwijzen van gedetineerden naar behandelprogramma's), maar toonde wel aan dat de theorie van Lipsky (1980) van toepassing was op een breed scala aan populaties, zoals maatschappelijk werkers (Ellis, 2007), politieagenten (Brown, 1981; Mastrofski e.a., 1995; Maynard-Moody \& Musheno, 2003) en rechters (Cowan \& Hitchings, 2007). Studies wezen daarnaast uit dat non-conformiteit aan voorgeschreven beleid kan leiden tot een beperkte toegang tot dienstverlening voor voornamelijk kansarme populaties (zie Brodkin \& Majmundar, 2010; Monnat, 2010; Moynihan \& Herd, 2010; Riccucci, 2005; Wenger \& Wilkins, 2009). Dit zou eveneens van toepassing kunnen zijn op de populatie die centraal staat in deze studie; het afwijken van beleidsregels door tra- 
jectbegeleiders zou kunnen leiden tot een verminderde toegang tot zorg voor een (selecte) groep gedetineerden.

De tweede aanname, waarin verwacht wordt dat een breed scala aan risicofactoren alsmede organisatorische omstandigheden van invloed zullen zijn op het verwijzen van gedetineerden naar programma's, is lastiger te onderbouwen met eerder onderzoek. Er is nooit nagegaan welke factoren van invloed waren op het verwijzen van gedetineerden naar (passende) programma's. Om onze verwachting te kunnen ondersteunen zijn wij daarom genoodzaakt te kijken naar de uitkomsten van studies in een aangrenzend onderzoeksveld: besluitvormingsprocessen door andere actoren in de strafrechtsketen. Dergelijke studies toonden aan dat risicofactoren en (factoren gerelateerd aan) het recidiverisico van invloed zijn op beslissingsprocessen van rechters (Hannah-Moffat \& Maurutto, 2012; zie ook Hartley e.a., 2007; Spohn, 2000; Zatz, 2000) en reclasseringswerkers (Carroll \& Burke, 1990; Meyer, 2001). Daarnaast bleek dat organisatorische omstandigheden justitiële besluitvorming eveneens kunnen beïnvloeden. Zo wees onderzoek uit dat beslissingen van rechters vaak variëren tussen geografische rechtsgebieden (zie bijvoorbeeld Kautt, 2002; Ulmer \& Johnson, 2004), en bleken bureaucratie (Engen \& Steen, 2000; Johnson e.a., 2008), grote caseloads (Johnson, 2006; Johnson e.a., 2008; Ulmer \& Bradley, 2006) en overbevolking in gevangenissen (Johnson, 2006; Ulmer \& Johnson, 2004) van invloed op gerechtelijke beslissingen, alsmede de mate waarin gekozen wordt voor vervroegde (voorwaardelijke) vrijlating (Glaser, 1985; Winfree e.a., 1990). Samenvattend zien we dat de factoren waarvan verwacht wordt dat ze verband houden met het verwijzen van gedetineerden naar programma's, in andere onderzoeksgebieden van invloed waren. Echter, we kunnen deze niet bevestigen met onderzoek op het terrein van de justitiële behandeling.

\section{De huidige studie}

Het doel van deze studie is tweeledig. Allereerst wordt getracht te achterhalen of verwijzingen naar gedragsinterventies in Nederlandse PI's conform de geldende richtlijnen plaatsvinden, namelijk op basis van RISc-scores op een aantal daarvoor aangewezen schalen. Daarnaast wordt nagegaan of risicofactoren en organisatorische omstandigheden van invloed waren op het verwijzen van gedetineerden naar behandelprogramma's.

\section{Methoden}

\section{Onderzoeksgroep en procedure}

Om de in deze bijdrage gestelde onderzoeksvragen te beantwoorden werden de gegevens geanalyseerd van 541 mannelijke gedetineerden die, tijdens hun verblijf in de gevangenis, deelnamen aan het programma TR. Deze onderzoeksgroep was 
onderdeel van de steekproef van het Prison Project, ${ }^{2}$ een grootschalig wetenschappelijk onderzoek naar de effecten van detentie. De steekproef van het Prison Project bestond uit de totale instroom van voorlopig gehechte, mannelijke gedetineerden, in de leeftijd van 18 t/m 65 jaar, geboren in Nederland, die instroomden in een huis van bewaring tussen oktober 2010 en maart 2011 $(\mathrm{N}=3.981)$. Van deze totale onderzoeksgroep kwam bijna 80 procent niet in aanmerking voor behandeling ( $\mathrm{n}=3.095)$, meestal veroorzaakt door een te kort strafrestant. Daarnaast namen 345 gedetineerden (8,6 procent) die in aanmerking kwamen voor het programma niet deel. De uiteindelijke steekproef bevatte dus 541 respondenten die deelnamen aan het programma TR en in dat kader verwezen konden worden naar een gedragsinterventie.

Om verwijzingen naar gedragsinterventies te kunnen bestuderen werd gebruik gemaakt van verschillende informatiebronnen. Allereerst werd door Reclassering Nederland risicotaxatie-informatie ter beschikking gesteld. Daarnaast verschafte de Dienst Justitiële Inrichtingen (DJI) informatie uit het registratiesysteem Tenuitvoerlegging persoonsgebonden straffen (TULP) en uit het Trajecteninformatiesysteem (TRIS), de database waarin alle activiteiten gerelateerd aan het programma TR worden geregistreerd (dat wil zeggen, de mate waarin gedetineerden voor het programma in aanmerking kwamen, daaraan deelnamen, en dit afrondden, alsmede gedragsinterventies waar zij aan deelnamen). Daarnaast werden registratiegegevens over capaciteit en bezetting in elke PI in Nederland, over elk jaar dat onze steekproef mogelijk was ingesloten, aangeleverd door de DJI. Om enkele aanvullende organisatorische kenmerken te verzamelen werd ten slotte een telefonische vragenlijst afgenomen bij alle PI's in Nederland, waarbij gevraagd werd naar informatie over het personeelsbestand en de beschikbaarheid van inhouse rehabilitatieprogramma's.

\section{Afhankelijke variabele}

De afhankelijke variabele van deze studie was type behandeling, die werd bepaald met behulp van de database TRIS. Zoals aangegeven worden in Nederlandse PI's vier typen gedragsinterventies aangeboden, waarvan alleen de CoVa-training en leefstijltraining met enige regelmaat werden toegepast (zie Bosma e.a., 2013). Helaas heeft eerder onderzoek niet duidelijk gemaakt wat hiervoor de reden was. Echter, gezien alle trainingen niet veelvuldig werden toegepast (Bosma e.a., 2013), de CoVa- en leefstijltraining meer voorkomende (Fischer e.a., 2012) problematiek aanpakken, en het uitvoeren van interventies soms lastig kan zijn in de beperkte tijd die beschikbaar is (IST, 2010), komt men vervolgens wellicht niet toe aan het opleggen van een arbeidsvaardighedentraining of agressieregulatietraining. Met oog op de huidige studie is in ieder geval besloten, gelet op het feit dat de laatste twee trainingen onder onze onderzoeksgroep te weinig voorkwamen ( $<10$ keer), deze niet mee te nemen in de analyses.

2 Het Prison Project wordt financieel ondersteund door de Universiteit Leiden, het Nederlands Studiecentrum Criminaliteit en Rechtshandhaving (NSCR), de Nederlandse Organisatie voor Wetenschappelijk Onderzoek (NWO) en de Universiteit Utrecht. 
Type behandeling (geen, CoVa-training, leefstijltraining of beide) werd gecodeerd als 0 voor gedetineerden die niet werden verwezen naar een gedragsinterventie, 1 voor gedetineerden verwezen naar CoVa-training, 2 voor gedetineerden die naar leefstijltraining werden verwezen, en 3 voor gedetineerden die naar beide programma's werden verwezen.

\section{Onafhankelijke variabelen}

Achtergrondkenmerken geïncludeerd in deze studie waren leeftijd, etniciteit (autochtoon versus allochtoon) en type (huidig) delict (geweldsdelict versus nietgeweldsdelict). Leeftijd en type delict werden vastgesteld met behulp van het registratiesysteem TULP. Etniciteit werd bepaald met behulp van de RISc-database. Naar voorbeeld van het CBS werden respondenten gekwalificeerd als niet-westers allochtoon als minimaal één ouder in een niet-westers land geboren was, en als westers allochtoon als minimaal één ouder in een westers land, anders dan Nederland, geboren was.

Risicotaxatie-uitkomsten werden verzameld met behulp van de RISc-database. De RISc is een gevalideerd (Van der Knaap e.a., 2012) instrument waarmee het risico op recidive wordt bepaald door middel van een gegenereerde (en gewogen) score op twaalf eerdergenoemde risicodomeinen. De gewogen schaalscores werden meegenomen in de huidige studie (NB Schaal 1 en 2 worden door de RISc-database samengevoegd tot één totaalscore).

Richtlijnen vastgelegd in diverse programmahandleidingen bepalen dat de RISc leidend moet zijn bij het verwijzen van delinquenten naar behandelprogramma's. Zo komen gedetineerden in aanmerking voor deelname aan CoVa-training als zij (a) een matig tot hoog recidiverisico hebben, blijkend uit een minimale RISctotaalscore van 32, en (b) er sprake is van cognitieve tekorten, aangetoond uit een gewogen score op de RISc-schaal denkpatronen, gedrag en vaardigheden van minimaal 4; en (c) een dader is niet uitgesloten op basis van aanvullende gronden (Ministerie van Justitie, 2007). Gedetineerden dienen te worden verwezen naar leefstijltraining indien er (a) sprake is van drugs-, alcohol- en/of gokproblematiek, aangetoond door een score op de RISc-schalen drugsmisbruik van ten minste 3 en/of alcoholmisbruik van ten minste 2 en/of financieel beheer en het inkomen van ten minste 5 , met een minimale score van 2 op vraag 5.4, mits (b) zij niet zijn uitgesloten op aanvullende gronden (SVG Verslavingsreclassering, 2009). Op basis van de inclusiecriteria werd in het kader van deze studie een variabele gemaakt die aangaf voor welke gedragsinterventie (geen, CoVa-training, leefstijltraining of beide) een gedetineerde op basis van RISc-uitkomsten in aanmerking kwam.

De organisatorische omstandigheden die in deze studie werden opgenomen, waren duur gevangenisstraf, bezettingsgraad, trajectbegeleider/gedetineerderatio en aangeboden behandelprogramma's (CoVa-training en leefstijltraining). Strafduur werd bepaald met behulp van TULP. De bezettingsgraad (de gemiddelde bezetting per jaar ten opzichte van de maximale capaciteit in dat jaar) werd berekend met behulp van officiële gegevens die werden aangeleverd door de DJI, en de trajectbegeleider/gedetineerde-ratio en aangeboden behandelprogramma's werden allemaal bepaald op basis van zelf verzamelde gegevens. 


\section{Analyses}

De onderzoeksgroep werd allereerst ingedeeld in vier groepen, op basis van de inhoud van hun TR-behandelprogramma ( $0=$ geen gedragsinterventies; $1=\mathrm{CoVa}$ -

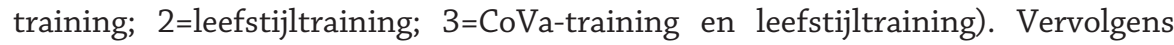
werd bepaald of gedetineerden in werkelijkheid ook werden verwezen naar de programma's waarvoor zij op basis van hun RISc-score in aanmerking kwamen, en werd bepaald of de groepen (juist geclassificeerde gedetineerden versus onjuist geclassificeerde gedetineerden) verschillend waren op achtergrondkenmerken, risicotaxatie-uitkomsten en organisatorische omstandigheden. Vervolgens werden beschrijvende statistieken op de onafhankelijke variabelen (achtergrondkenmerken, risicotaxatie-uitkomsten en organisatorische omstandigheden) berekend en werden groepsverschillen geanalyseerd. Met behulp van een multivariate multinomiale logistische regressieanalyse werd nagegaan in welke mate de onafhankelijke variabelen van invloed waren op verwijzing naar de vier programmavarianten. Vanwege het ruime aantal onafhankelijke variabelen en de relatief kleine onderzoeksgroepen werd echter eerst een serie univariate multinomiale logistische regressieanalyses uitgevoerd, waarna variabelen op basis van hun p-waarde (in navolging van Hosmer en Lemeshow (2000) werd een cut-offwaarde van p<.15 gehanteerd) werden opgenomen in het multivariate multinomiale model.

\section{Resultaten}

Het verkennen van discrepanties in verwijzingen naar gedragsinterventies Consultatie van de TRIS-database wees uit dat van de totale onderzoeksgroep van 541 TR-deelnemers 50,3 procent $(\mathrm{n}=272)$ niet naar een gedragsinterventie werd verwezen, terwijl anderen werden verwezen naar CoVa-training ( $\mathrm{n}=126,23,3$ procent), leefstijltraining ( $n=61,11,3$ procent) of beide ( $n=82,15,2$ procent).

Allereerst is in kaart gebracht in welke mate gedetineerden werden verwezen naar programma's waarnaar zij op basis van risicotaxatie-uitkomsten (RISc-score) verwezen zouden moeten worden. Op basis van RISc-scores bleek dat, in lijn met de geldende inclusiecriteria voor CoVa- en leefstijltraining, 215 gedetineerden (39,7 procent) niet verwezen zouden moeten worden naar een gedragsinterventie, en dat 326 gedetineerden (60,3 procent) verwezen zouden moeten worden naar een CoVa-training, leefstijltraining of beide. Wanneer we de werkelijke verwijzingen naast deze groepering op basis van RISc-scores leggen (zoals weergegeven in tabel 1), zien we echter grote verschillen. Meer dan de helft van de gedetineerden ( $n=302,55,9$ procent) bleek op basis van onze analyse verkeerd geclassificeerd. Dit resulteerde in drie typen fouten. Allereerst werden er gedetineerden verwezen naar een gedragsinterventie die op basis van hun RISc-score geen behandeling nodig hadden $(n=72)$. Ten tweede werden er gedetineerden niet verwezen die op basis van hun RISc-score wel behoefte hadden aan een gedragsinterventie $(n=129)$, en ten slotte werden er gedetineerden verwezen naar het verkeerde type behandeling $(\mathrm{n}=101)$. 


\section{Tabel 1 Correcte en incorrecte classificaties}

Correct geclassificeerd

Incorrect geclassificeerd

Verwezen naar gedragsinterventie, zou niet verwezen moeten worden op basis van RISc $(n=72)$

Niet verwezen naar gedragsinterventie, zou verwezen moeten worden op basis van RISc $(n=129)$

Verwezen naar het verkeerde type interventie op basis van RISc $(n=\mid 0 I)$

Totaal

$541(100 \%)$
$239(44,1 \%)$

$302(55,9 \%)$

Tabel 2

Kruistabel TR-verwijzingen en eigen analyse gebaseerd op RIScuitkomsten

\begin{tabular}{|c|c|c|c|c|c|}
\hline & \multicolumn{4}{|c|}{$\begin{array}{l}\text { Verwijzingen naar interventies in het kader van } \\
\text { TR }\end{array}$} & \multirow[b]{2}{*}{ Totaal } \\
\hline & Geen & CoVa & Leefstijl & Beide & \\
\hline Geen, gebaseerd op RISc & $143(52,6 \%)$ & $29(23,0 \%)$ & $18(29,5 \%)$ & $25(30,5 \%)$ & 215 \\
\hline CoVa, gebaseerd op RISc & $58(21,3 \%)$ & $47(37,3 \%)$ & $13(21,3 \%)$ & $16(19,5 \%)$ & 134 \\
\hline $\begin{array}{l}\text { Leefstijltraining, gebaseerd } \\
\text { op RISc }\end{array}$ & $33(12,1 \%)$ & $12(9,5 \%)$ & $17(27,9 \%)$ & $9(\mathrm{II}, 0 \%)$ & 71 \\
\hline Beide, gebaseerd op RISc & $38(14,0 \%)$ & $38(30,2 \%)$ & $13(2 \mid, 3 \%)$ & $32(39,0 \%)$ & 121 \\
\hline Totaal & 272 (I00\%) & $126(100 \%)$ & 61 (100\%) & 82 (I00\%) & 541 \\
\hline
\end{tabular}

In tabel 2 is een gedetailleerder beeld gegeven, waarin het type gedragsinterventie waarnaar gedetineerden werden verwezen, is afgezet tegen de gedragsinterventie waarnaar zij op basis van hun RISc-scores verwezen zouden moeten worden.

Om de twee groepen (correct geclassificeerden en incorrect geclassificeerden) verder te bestuderen werd een analyse uitgevoerd op achtergrondkenmerken. Zoals getoond in tabel 3, verschillen de twee groepen op een aantal variabelen. Over het algemeen bleek dat gedetineerden die correct geclassificeerd waren (wat inhoudt dat zij verwezen werden naar gedragsinterventies op basis van hun RISc-score) vaker gedetineerd waren voor een niet-gewelddadig delict dan niet-correct geclassificeerden. Daarnaast bleken zij over het algemeen lager te scoren op een zestal RISc-schalen, te weten delictgeschiedenis, huidig delict en delictpatroon; opleiding, werk en leren; inkomen en omgaan met geld; drugsgebruik; denkpatronen, gedrag en vaardigheden; en houding. Ten slotte bleken de twee groepen te verschillen met betrekking tot strafduur. Samenvattend kunnen we stellen dat gedetineerden die correct geclassificeerd werden, in vergelijking tot incorrect geclassificeerden, een lager-risicogroep betrof, veroordeeld waren tot een kortere strafduur en voor een minder ernstig delict.

De gepresenteerde analyses tonen aan dat er discrepanties zijn tussen de voorgeschreven richtlijnen ten aanzien van het verwijzen van gedetineerden naar 
Tabel 3 Classificatie en achtergrondkenmerken

\begin{tabular}{|c|c|c|c|c|}
\hline & \multirow{2}{*}{$\begin{array}{l}\text { Correct geclas- } \\
\text { sificeerd } \\
(n=239) \\
M(S D) / \%\end{array}$} & \multirow{2}{*}{$\begin{array}{l}\text { Incorrect } \\
\text { geclassificeerd } \\
(n=302) \\
M(S D) / \%\end{array}$} & \multicolumn{2}{|c|}{ Totaal $(\mathrm{N}=54 \mathrm{I})$} \\
\hline & & & $M(S D) / \%$ & Sig. \\
\hline \multicolumn{5}{|l|}{ Achtergrondkenmerken } \\
\hline Leeftijd (in jaren) & $29,9(10.8)$ & $29,7(10.2)$ & $29,8(10.4)$ & \\
\hline Etniciteit (autochtoon) & 40,7 & 44,8 & 42,5 & \\
\hline $\begin{array}{l}\text { Type delict (niet-geweldda- } \\
\text { dig) }\end{array}$ & 30,4 & 42,2 & 37,0 & $* *$ \\
\hline \multicolumn{5}{|l|}{ Risicotaxatie-uitkomsten } \\
\hline $\begin{array}{l}\text { Delictgeschiedenis, huidig } \\
\text { delict en delictpatroon } \\
(0-50)\end{array}$ & $17,0(13,0)$ & $20,2(12,7)$ & $18,8(12,9)$ & $* *$ \\
\hline $\begin{array}{l}\text { Huisvesting en wonen } \\
(0-12)\end{array}$ & $3,9(4,2)$ & $4,1(4,2)$ & $4,0(4,2)$ & \\
\hline $\begin{array}{l}\text { Opleiding, werk en leren } \\
(0-20)\end{array}$ & $8,4(6,8)$ & $10,2(6,3)$ & $9,4(6,6)$ & $* *$ \\
\hline $\begin{array}{l}\text { Inkomen en omgaan met } \\
\text { geld }(0-12)\end{array}$ & $4,5(3,7)$ & $5,4(3,8)$ & $5,0(3,8)$ & $*$ \\
\hline $\begin{array}{l}\text { Relaties met partner, gezin } \\
\text { en familie }(0-6)\end{array}$ & $2,5(1,9)$ & $2,8(1,6)$ & $2,7(1,7)$ & \\
\hline $\begin{array}{l}\text { Relaties met vrienden en } \\
\text { kennissen }(0-15)\end{array}$ & $6,0(4,6)$ & $6,7(4,2)$ & $6,4(4,4)$ & \\
\hline Drugsgebruik (0-15) & $4,7(5,4)$ & $6,5(5,0)$ & $5,7(5,2)$ & $* * *$ \\
\hline Alcoholgebruik (0-5) & $\mathrm{I}, 4(\mathrm{I}, 9)$ & I,8 $(I, 8)$ & $\mathrm{I}, 6(\mathrm{I}, 9)$ & \\
\hline Emotioneel welzijn (0-6) & $2,2(1,8)$ & $2,2(1,6)$ & $2,2(1,7)$ & \\
\hline $\begin{array}{l}\text { Denkpatronen, gedrag en } \\
\text { vaardigheden }(0-12)\end{array}$ & $7,4(3,4)$ & $8,4(2,7)$ & $7,9(3,1)$ & $* * *$ \\
\hline Houding (0-15) & $5,6(4,8)$ & $7,0(4,4)$ & $6,4(4,6)$ & $* * *$ \\
\hline \multicolumn{5}{|l|}{$\begin{array}{l}\text { Organisatorische omstan- } \\
\text { digheden }\end{array}$} \\
\hline Strafduur (in dagen) & $580,95(750,6)$ & $774,3(1083,3)$ & $666,4(916,8)$ & $* *$ \\
\hline Bezettingsgraad & 92,1 & 93,2 & 97,9 & \\
\hline $\begin{array}{l}\text { Trajectbegeleider/gedeti- } \\
\text { neerde-ratio }\end{array}$ & II5,3 (67,0) & $109,6(66,0)$ & $112,1(66,5)$ & \\
\hline $\begin{array}{l}\text { CoVa-training beschikbaar } \\
\text { (nee) }\end{array}$ & 79,1 & 83,4 & 81,5 & \\
\hline $\begin{array}{l}\text { Leefstijltraining beschikbaar } \\
\text { (nee) }\end{array}$ & 76,6 & 80,8 & 78,9 & \\
\hline
\end{tabular}

gedragsinterventies en de praktijk ervan. Onze analyse was echter puur gebaseerd op RISc-uitkomsten. Dit houdt in dat geen rekening gehouden werd met andere factoren die wellicht van invloed waren op het verwijzen van gedetineerden naar 
behandelingen, zoals (een gebrek aan) motivatie onder deelnemers. Wellicht is het vorenstaande daarom een enigszins simplistische weergave van zaken. Wel roept het de vraag op, gezien de aangewezen RISc-schalen niet leidend waren bij het verwijzen van gedetineerden naar programma's, welke factoren verwijzingen dan (eveneens) hebben beïnvloed.

\section{Determinanten van verwijzingen naar gedragsinterventies}

Gezien de RISc-scores op een aantal aangewezen items in veel gevallen niet leidend waren voor het maken van beslissingen over het verwijzen van gedetineerden naar gedragsinterventies, wordt nu bekeken welke andere factoren wel van invloed waren. Allereerst worden daartoe de gedetineerden verwezen naar vier programmavarianten vergeleken op achtergrondkenmerken.

Zoals in tabel 4 te zien is, waren er allereerst groepsverschillen met betrekking tot de kenmerken leeftijd en etniciteit. Uit analyses bleek dat, over het algemeen, oudere gedetineerden vaker behoorden tot de groep gedetineerden die niet werden verwezen naar een gedragsinterventie, in vergelijking met gedetineerden die naar CoVa-training of beide typen trainingen werden verwezen. Daarnaast kwam naar voren dat gedetineerden met een allochtone achtergrond oververtegenwoordigd waren in de CoVa-traininggroep. 


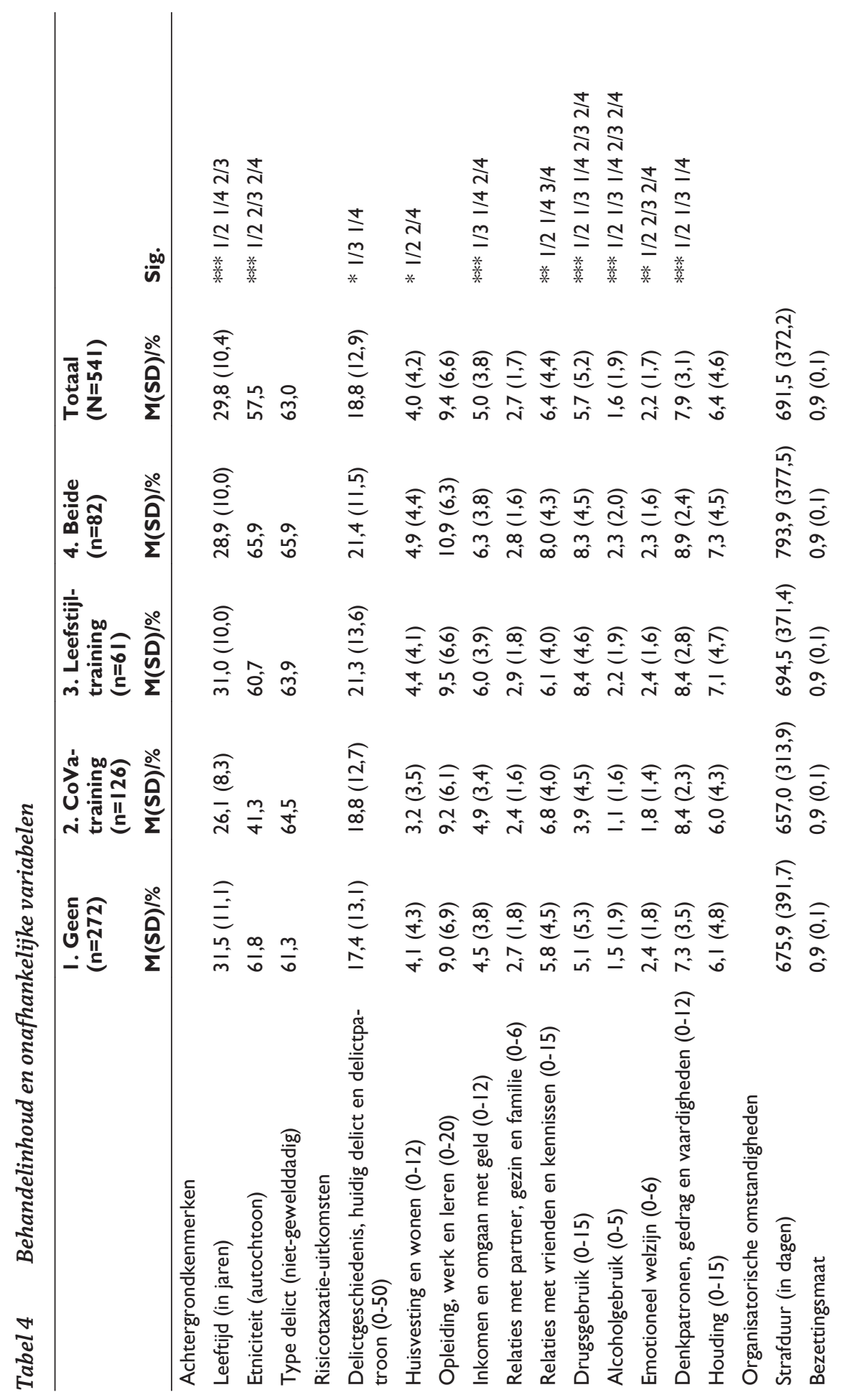




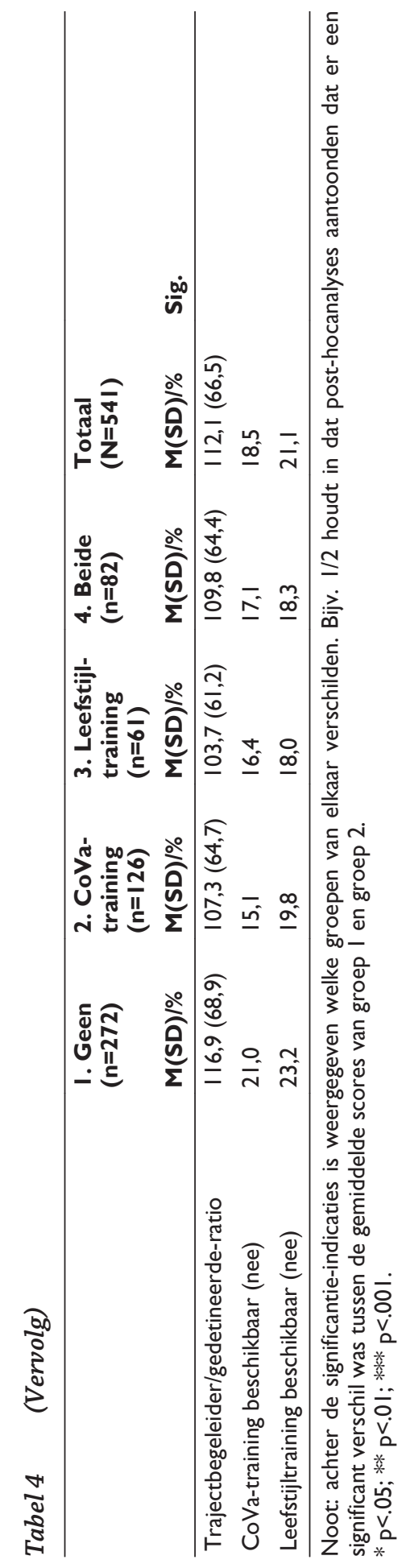


Er waren ook groepsverschillen met betrekking tot risicotaxatie-uitkomsten op acht van de elf schalen. Te weten delictgeschiedenis, huidig delict en delictpatroon; huisvesting en wonen; inkomen en omgaan met geld; relaties met vrienden en kennissen; drugsgebruik; alcoholgebruik; emotioneel welzijn; en denkpatronen, gedrag en vaardigheden. Over het algemeen werd door gedetineerden die niet waren verwezen naar een behandelprogramma het laagst gescoord op diverse risicodomeinen; zo bleek bijvoorbeeld dat met betrekking tot het domein delictgeschiedenis, huidig delict en delictpatroon gedetineerden met een lage score vaker niet verwezen werden naar behandeling, in vergelijking tot gedetineerden die verwezen werden naar leefstijltraining en beide typen behandeling. Er waren echter ook uitzonderingen, zo werd op de schaal emotioneel welzijn het laagst gescoord door gedetineerden die naar CoVa-training werden verwezen, in vergelijking met gedetineerden in de overige drie groepen. Met betrekking tot organisatorische omstandigheden werden, zoals te zien is in tabel 4 , geen verschillen gevonden.

Alvorens over te gaan naar de multivariate analyses, werd een serie univariate analyses uitgevoerd, op basis waarvan variabelen met een significante univariate test (dat wil zeggen, met een p-waarde lager dan .15) opgenomen werden in het multivariate model. Zoals in tabel 5 is te zien, werden de variabelen leeftijd en etniciteit, alle elf risicotaxatieschalen en strafduur en bezettingsgraad in het multivariate model opgenomen. 


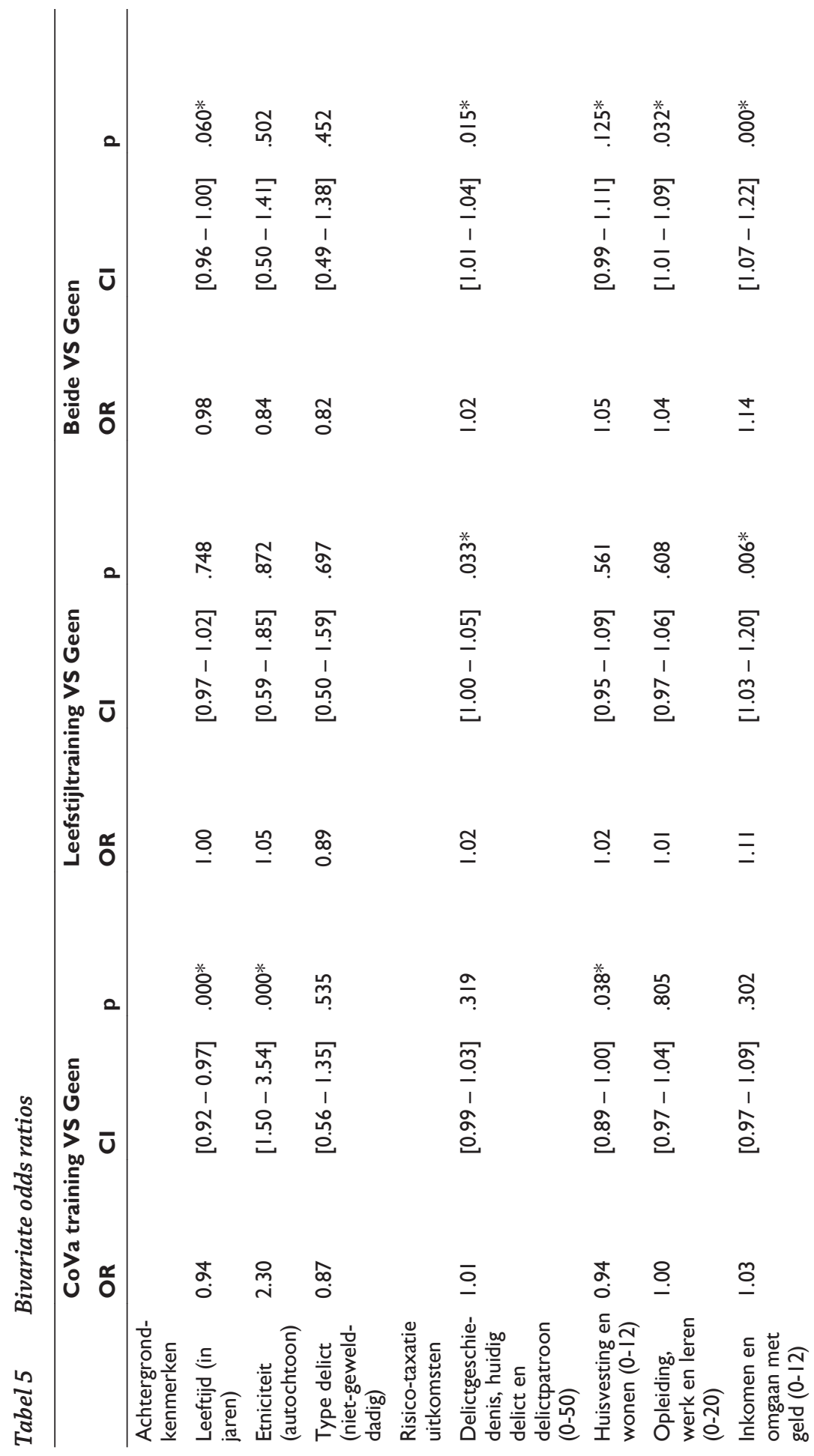




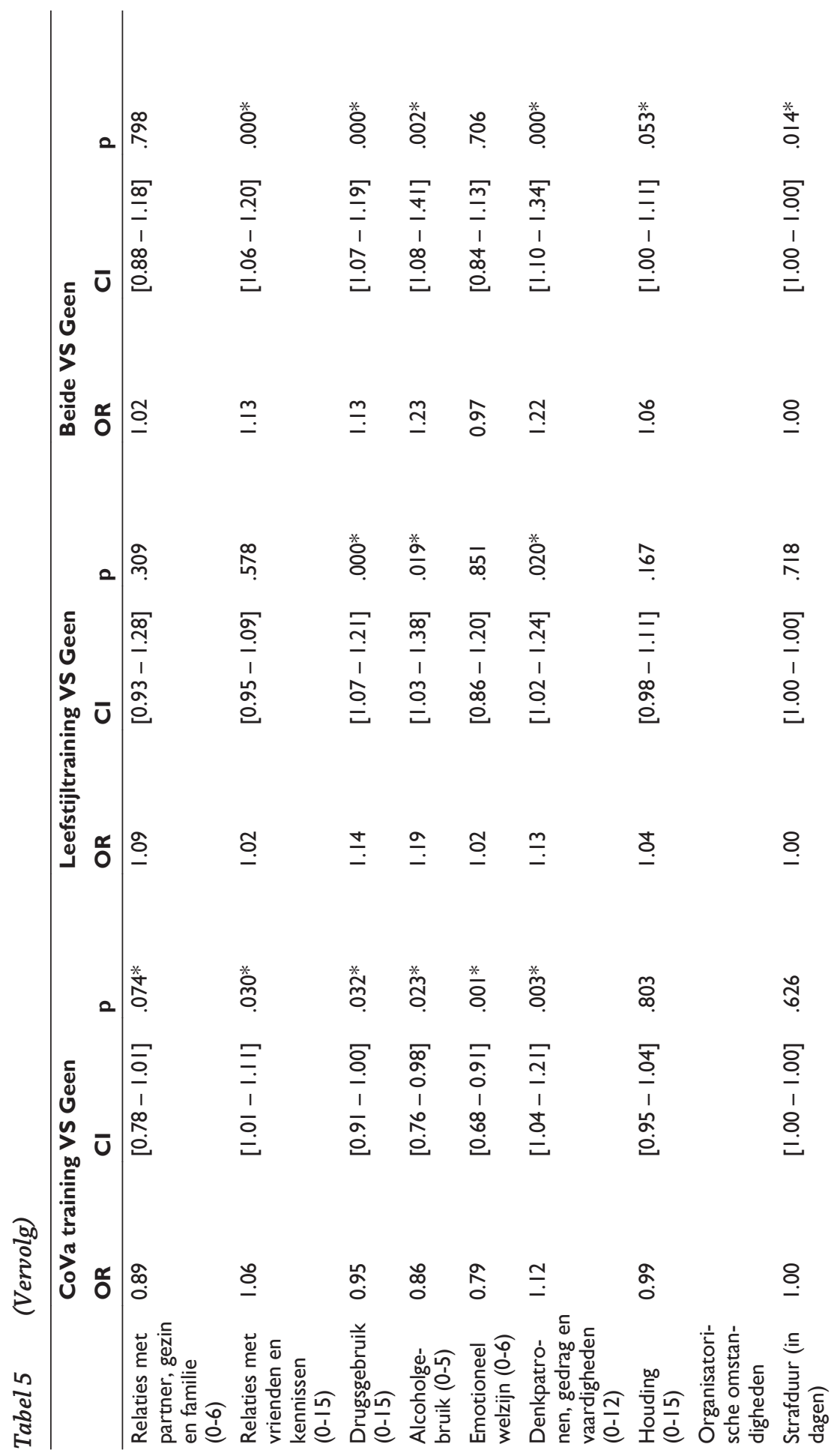




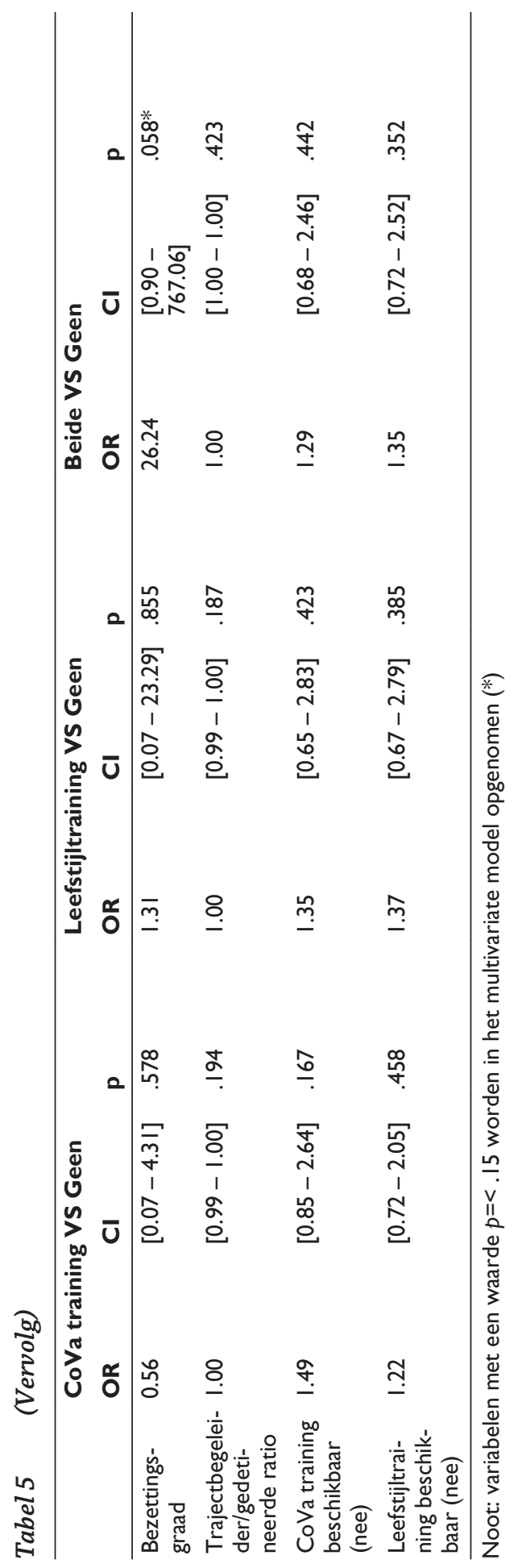


De resultaten van de multinomiale regressieanalyse, waarbij de invloed van risicotaxatie-uitkomsten en organisatorische omstandigheden op behandelinhoud getoetst werd, zijn weergegeven in tabel 6 . Gedetineerden die niet werden verwezen naar een programma vertegenwoordigen de controlegroep. 


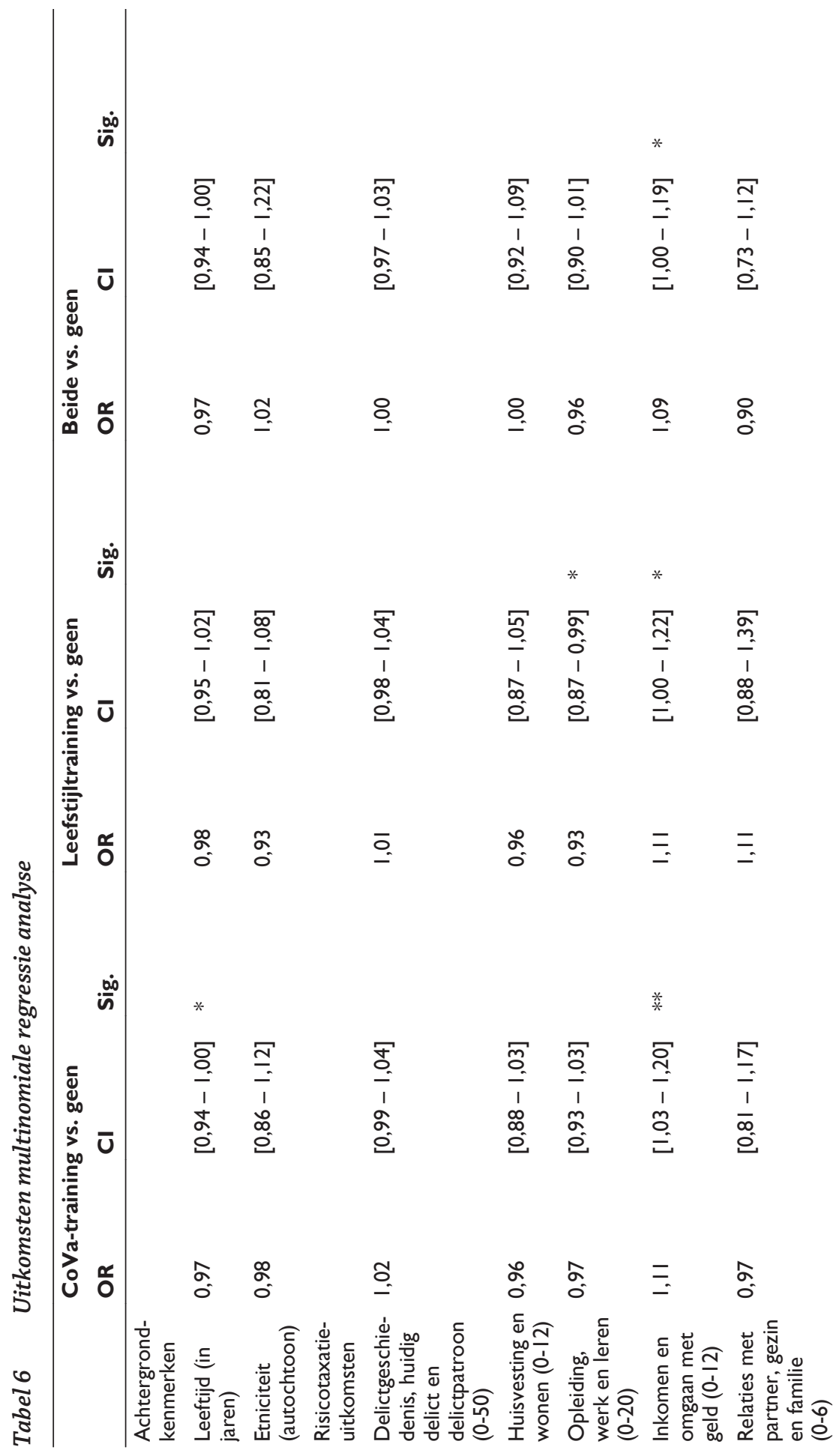




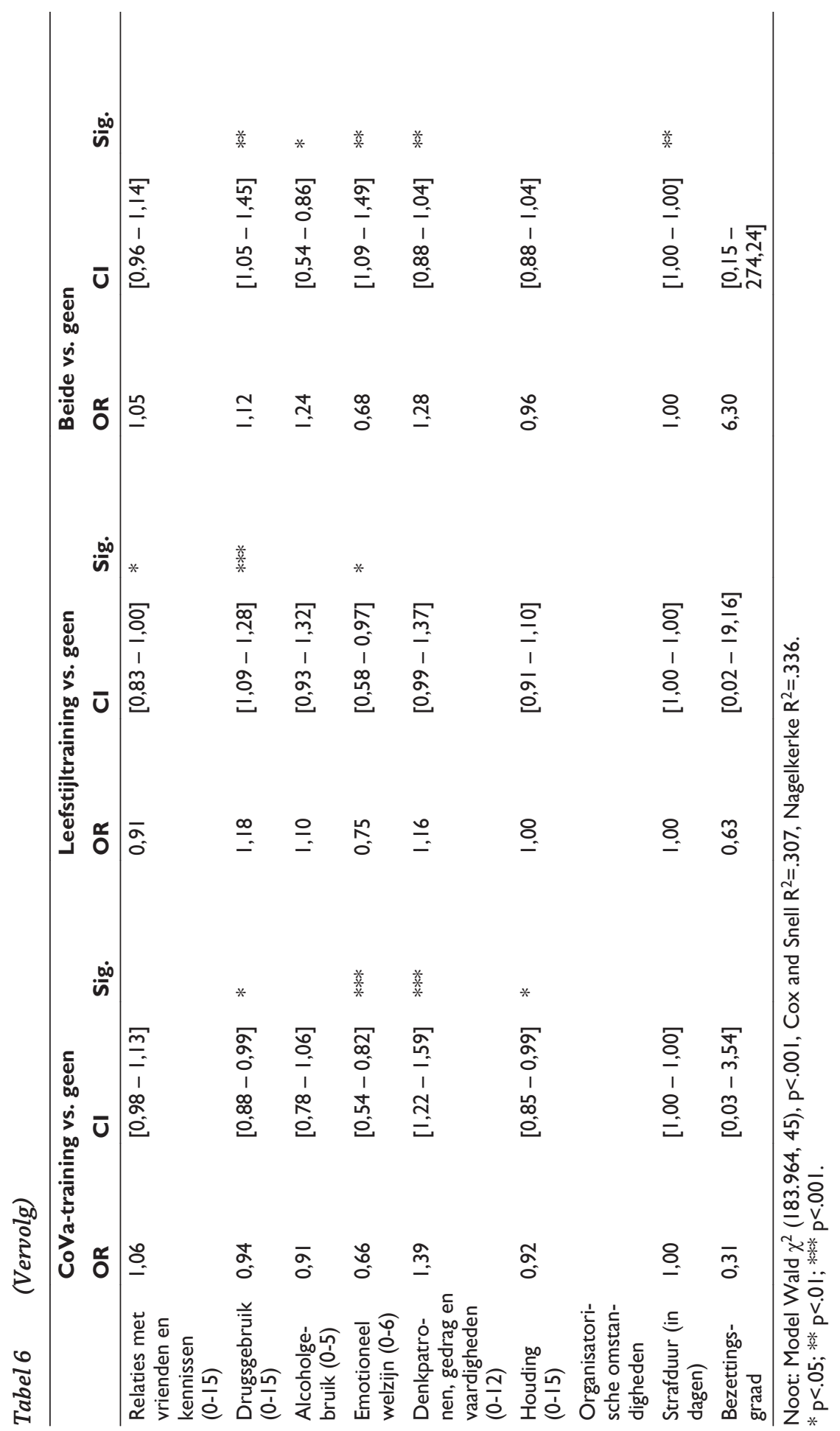


Verschillende risicotaxatie-uitkomsten bleken gerelateerd aan behandelverwijzingen. Zo had een hogere score op de schaal opleiding, werk en leren een negatieve invloed op verwijzingen naar leefstijltraining. Met betrekking tot problemen met inkomen en omgaan met geld toonde analyse aan dat een hogere score was gerelateerd aan een hogere kans om verwezen te worden naar CoVa-training, leefstijltraining en beide typen interventies. Vervolgens bleek dat gedetineerden met een hogere score op het domein relaties met vrienden en kennissen een lagere kans hadden om verwezen te worden naar leefstijltraining. Daarnaast kwam uit de analyse naar voren dat een hogere score op het domein drugsgebruik de kansen op een verwijzing naar CoVa-training verlaagde, terwijl het de kansen op verwijzing naar leefstijltraining en beide trainingen verhoogde. Meer gerapporteerde problemen met betrekking tot alcoholgebruik verhoogden eveneens de kans om beide typen trainingen te moeten volgen. Vervolgens kwam naar voren dat gedetineerden met een hogere score op het domein emotioneel welzijn een substantieel lagere kans hadden om verwezen te worden naar een CoVa-training, leefstijltraining en beide typen behandeling. Met betrekking tot de schaal denkpatronen, gedrag en vaardigheden bleek dat een hoge score de kans op verwijzing naar leefstijltraining en beide typen trainingen verhoogde. En ten slotte kwam uit de analyse naar voren dat een hogere score op de schaal houding verwijzingen naar CoVa-trainingen negatief beïnvloedde. Wat organisatorische kenmerken betreft kwam naar voren dat alleen strafduur was gerelateerd aan verwijzingen naar gedragsinterventies. Een langere strafduur (gemeten in dagen) verhoogde de kans dat een gedetineerde werd verwezen naar beide typen trainingen. Met het oog op achtergrondkenmerken ten slotte, bleek dat een hogere leeftijd negatief was gerelateerd aan behandelverwijzingen naar CoVa-training.

\section{Discussie}

Met deze studie werd getracht te beoordelen of behandelverwijzingen in Nederlandse PI's conform de geldende voorschriften plaatsvinden. Daarmee is feitelijk getoetst of er sprake is van een discrepantie tussen voorgeschreven beleid en beleid zoals uitgevoerd in de praktijk, zoals op basis van het werk van Lipsky (1980) kan worden verwacht. Daarnaast is nagegaan of risicofactoren en organisatorische omstandigheden van invloed waren op het verwijzen van gedetineerden naar behandelprogramma's.

\section{Conclusie en discussie}

Uit de resultaten kan geconcludeerd worden dat officiële richtlijnen over het algemeen niet leidend waren bij het verwijzen van gedetineerden naar gedragsinterventies. Dit werd allereerst aangetoond doordat er grote discrepantie was tussen daadwerkelijke verwijzing van gedetineerden naar programma's en de programma's waarnaar zij verwezen hadden moeten worden op basis van hun RIScuitkomsten. Gedetineerden met minder (ernstige) risicofactoren werden daarbij vaker verwezen naar een passend programma. Ten tweede werd dit aangetoond door een breed scala van factoren in een multivariaat model op te nemen. Ook 
daar werd niet aangetoond dat de aangewezen RISc-domeinen een veel grotere samenhang hadden met opgelegde gedragsinterventies dan andere factoren. Als voorbeeld: er werd niet aangetoond dat de domeinen alcoholgebruik en drugsgebruik de kans op verwijzing naar leefstijltraining sterk verhoogden.

Aangezien de studie aantoonde dat de behandelverwijzingen in Nederlandse PI's niet in overeenstemming waren met geldende beleidsrichtlijnen ondersteunt dit onderzoek de SLBT van Lipsky (1980), wat suggereert dat werknemers in de publieke dienstverlening beleid niet altijd toepassen zoals voorgeschreven. Dit resultaat is zoals verwacht, en komt overeen met de resultaten van eerder onderzoek op andere terreinen (Brodkin, 2012). Consequentie van de gevonden discrepantie tussen beleid en praktijk is dat Nederlandse gedetineerden die in aanmerking komen voor (en behoefte hebben aan) behandeling, geen toegang hebben tot de diensten waar zij recht op hebben. Dit resultaat is in lijn met de uitkomsten van studies die concludeerden dat kwetsbare bevolkingsgroepen vaker beperkte toegang hebben tot diensten en zorg (Brodkin \& Majmundar, 2010; Monnat, 2010; Moynihan \& Herd, 2010; Riccucci, 2005; Wenger \& Wilkins, 2009).

Daarnaast werd aangetoond dat gedetineerden met minder (ernstige) risicofactoren vaker correct werden geclassificeerd. Dit resultaat was zoals verwacht, en is eveneens in lijn met het werk van Lipsky (1980; 2010), die stelde dat frontlijnwerkers omgaan met werkdruk door prioriteit te geven aan gemakkelijkere en beheersbaardere gevallen. Een copingstrategie die door Lipsky ook wel creaming wordt genoemd, en waarvan eerder onderzoek (Tummers e.a., 2015) liet zien dat deze ook door andere overheidsmedewerkers gebruikt wordt.

Als de in beleidsrichtlijnen aangewezen factoren niet leidend waren bij het verwijzen van gedetineerden naar programma's, welke factoren waren dan wel van invloed? Twee opmerkingen: allereerst lijkt het zo te zijn dat het brede scala van RISc-uitkomsten hierbij een rol speelt. Dit lijkt op het eerste oog weinig problematisch, een hogere score op veel RISc-domeinen toont immers aan dat een gedetineerde een hoger risico op recidive heeft, en onderzoek toonde aan dat dit de juiste behandeldoelgroep is (Andrews e.a., 1990; Dowden \& Andrews, 2000). Om aan te tonen dat dit mogelijk wel problematisch is, kunnen we, net als in de inleiding werd gedaan, een parallel trekken met de medische wereld: zo krijgt een patient antibiotica bij een longontsteking en bloeddrukverlagers bij een te hoge bloeddruk. Het feit dat een gedetineerde een hoog risico heeft, en behandeling nodig is, zegt niets over het type behandeling dat geïndiceerd is. Het feit dat de behandelingen in deze studie in een substantieel deel van de gevallen niet aansloten bij de klachten, is onwenselijk, en maakt dat wij onze verwachtingen ten aanzien van de effectiviteit van gedragsinterventies in het verminderen van recidive onder deelnemers wellicht moeten temperen. Ten tweede zien we dat organisatorische omstandigheden, in tegenstelling tot verwacht, omdat factoren zoals overbevolking in de gevangenis andere actoren in de strafrechtsketen wel beïnvloeden (Glaser, 1985; Winfree e.a., 1990), over het algemeen niet van invloed op behandelverwijzingen zijn, met uitzondering van detentieduur. Daarnaast werd een klein effect van leeftijd gevonden, waarbij jongere gedetineerden vaker werden verwezen naar CoVa-training. Dit kan wellicht verklaard worden doordat zij als meer leerbaar beschouwd worden, zeker betreffende cognitieve vaardigheden 
zoals impulscontrole. Ten slotte kan worden geconcludeerd dat een groot deel van de variantie in behandelinhoud onverklaard bleef. Met andere woorden: er zijn factoren die in deze studie niet meegenomen werden, die van invloed waren op behandelverwijzingen. Het plaatje is in die zin dus allerminst compleet en vervolgonderzoek is nodig om hier meer duidelijkheid over te kunnen verschaffen.

\section{Beperkingen en aanbevelingen voor toekomstige studies}

Dit onderzoek had een aantal beperkingen, allereerst met betrekking tot het design van de studie. Om beslissingsprocessen ten aanzien van het verwijzen van gedetineerden naar gedragsinterventies te kunnen verklaren, kon geen beroep gedaan worden op een door theorie en eerder onderzoek aangewezen set variabelen. In plaats daarvan werd een exploratief model getoetst met variabelen die van invloed waren gebleken in studies uit een aangrenzend onderzoeksveld. Hoewel theoretisch en empirisch onderbouwd, is het zeker denkbaar dat ook andere factoren hebben bijgedragen aan behandelverwijzingen. Meer onderzoek is nodig om dit nader te bestuderen.

Ten tweede waren de gebruikte data voor een groot deel beperkt tot officiële registratiegegevens. Dat heeft als voordeel dat er een nagenoeg complete dataset beschikbaar was, met RISc-gegevens over een grote groep gedetineerden. Dit heeft echter als nadeel dat we ons moesten beperken tot de variabelen die in de registratiebestanden beschikbaar waren. Daarnaast was er geen achtergrondinformatie beschikbaar over de trajectbegeleiders, en kon slechts een beperkt aantal organisatorische kenmerken meegenomen worden. Het zou een grote vooruitgang zijn als toekomstig onderzoek meer variabelen, over zowel de gedetineerde en de verwijzer als de context, mee zou kunnen nemen.

Ten slotte, een enorme hoeveelheid studies heeft aangetoond dat gedragsinterventies effectief kunnen zijn in het verminderen van recidive onder ex-gedetineerden, mits zij toegepast worden op de juiste doelgroep (Andrews \& Bonta, 2010; Andrews e.a., 1990). Het lijkt erop, gezien de resultaten van dit onderzoek, dat gedragsinterventies in Nederland niet (volledig) in overeenstemming met de risicoscores van individuele gedetineerden worden toegepast. Dit is niet conform de richtlijnen voor effectief behandelen, en zou de effectiviteit van gedragsinterventies negatief kunnen beïnvloeden. Aanvullend onderzoek is nodig om na te gaan of dit het geval is.

\section{Literatuur}

Adviesbureau Van Montfoort \& Reclassering Nederland (2004). RISc versie 1.0. Recidive Inschattingsschalen. Handleiding. Utrecht: Reclassering Nederland.

Andrews, D.A. \& Bonta, J. (2010). Rehabilitating criminal justice policy and practice. Psychology, Public Policy and Law, 16, 39-55.

Andrews, D.A., Bonta, J. \& Hoge, R.D. (1990). Classification for effective rehabilitation: rediscovering psychology. Criminal Justice and Behavior, 17, 19-52.

Andrews, D.A., Zinger, I., Hoge, R.D., Bonta, J., Gendreau, P. \& Cullen, F.T. (1990). Does correctional treatment work? A clinically relevant and psychologically informed metaanalysis. Criminology, 28, 369-404. 
Bosma, A.Q., Kunst, M.J.J. \& Nieuwbeerta, P. (2013). Rehabilitatie in Nederlandse gevangenissen. Wat is de stand van zaken ten aanzien van de uitvoering en doelmatigheid van het programma Terugdringen Recidive? Tijdschrift voor Veiligheid, 12(3), 3-19.

Brodkin, E.Z. (2012). Reflections on street-level bureaucracy: past, present, and future. Public Administration Review, 72(6), 940-949.

Brodkin, E.Z. \& Majmundar, M. (2010). Administrative exclusion: organizations and the hidden costs of welfare claiming. Journal of Public Administration Research and Theory, 20, 827-846.

Brown, M.K. (1981). Working the street. New York: Russell Sage Foundation.

Carroll, J.S. \& Burke, P.A. (1990). Evaluation and prediction in expert parole decisions. Criminal Justice and Behavior, 17(3), 315-332.

Cowan, D. \& Hitchings, E. (2007). 'Pretty boring stuff': district judges and housing possession proceedings. Social \& Legal Studies, 16(3), 363-382.

Dirkzwager, A.J.E., Nieuwbeerta, P. \& Fiselier, J.P.S. (2009). Onbedoelde gevolgen van vrijheidsstraffen: een literatuurstudie. Tijdschrift voor Criminologie, 51(1), 21-41.

Dowden, C. \& Andrews, D.A. (2000). Effective correctional treatment and violent reoffending: a meta-analysis. Canadian Journal of Criminology, 42, 449.

Ellis, K. (2007). Direct payments and social work practice: the significance of 'street-level bureaucracy' in determining eligibility. British Journal of Social Work, 37(3), 405-422.

Ellis, K. (2011). Street-level bureaucracy revisited: the changing face of frontline discretion in adult social care in England. Social Policy and Administration, 45(3), 221-244.

Engen, R.L. \& Steen, S. (2000). The power to punish: discretion and sentencing reform in the war on drugs. American Journal of Sociology, 1357-1395.

Fineman, S. (1998). Street-level bureaucrats and the social construction of environmental control. Organization Studies, 19(6), 953-974.

Fischer, T.F.C., Captein, W.J.M. \& Zwirs, B.W.C. (2012). Gedragsinterventies voor volwassen justitiabelen. Den Haag: Boom Lemma uitgevers.

Gendreau, P. (1996). Offender rehabilitation: what we know and what needs to be done. Criminal Justice and Behaviour, 23, 144-161.

Gendreau, P., Little, T. \& Goggin, C. (1996). A meta-analysis of the predictors of adult offender recidivism: what works? Criminology, 34, 575-607.

Glaser, D. (1985). Who gets probation and parole: case study versus actuarial decision making. Crime \& Delinquency, 31(3), 367-378.

GW \& 3RO (2007). Programma Terugdringen Recidive. Draaiboek samenwerking gevangeniswezen en reclassering. Den Haag: DJI.

Hannah-Moffat, K. (2005). Criminogenic needs and the transformative risk subject Hybridizations of risk/need in penalty. Punishment \& Society, 7(1), 29-51.

Hannah-Moffat, K. \& Maurutto, P. (2012). Shifting and targeted forms of penal governance: bail, punishment and specialized courts. Theoretical Criminology, 16(2), 201-219.

Hartley, R.D., Maddan, S. \& Spohn, C.C. (2007). Concerning conceptualization and operationalization: sentencing data and the focal concerns perspective. A research note.

Southwest Journal of Criminal Justice, 4(1), 58-78.

Hosmer, D.W. \& Lemeshow, S. (2000). Applied logistic regression. New York: Wiley.

Howard, P., Clark, D. \& Garnham, N. (2003). An evaluation and validation of the Offender Assessment System (OASys). OASys Central Research Unit: Report to HM Prison Service and National Probation Service.

Inspectie Veiligheid en Justitie (2016). Risico's implementatie Masterplan DJI 2013-2018. Den Haag: Ministerie van Veiligheid en Justitie. 
IST (Inspectie voor de Sanctietoepassing) (2010). Samenwerkingsmodel Terugdringen Recidive. Den Haag: Inspectie voor de Sanctietoepassing.

Johnson, B.D. (2006). The multilevel context of criminal sentencing: integrating judge-and county-level influences. Criminology, 44(2), 259-298.

Johnson, B.D., Ulmer, J.T. \& Kramer, J.H. (2008). The social context of guidelines circumvention: the case of federal district courts. Criminology, 46(3), 737-783.

Kautt, P.M. (2002). Location, location, location: interdistrict and intercircuit variation in sentencing outcomes for federal drug-trafficking offenses. Justice Quarterly, 19(4), 633-671.

Knaap, L.M. van der, Leenarts, L.E.W., Born, M.P. \& Oosterveld, P. (2012). Re-evaluating inter-rater reliability in offender risk assessment. Crime \& Delinquency, 58(1), 147-163.

Latessa, E.J., Cullen, F.T. \& Gendreau, P. (2002). Beyond correctional quackery: professionalism and the possibility of effective treatment. Federal Probation, 66, 43.

Lehmann Nielsen, V. (2006). Are street-level bureaucrats compelled or enticed to cope? Public Administration, 84(4), 861-889.

Lipsky, M. (1980). Street-level bureaucracy. Dilemmas of the individual in public services. New York: Russel Sage Foundation.

Lipsky, M. (2010). Street-level bureaucracy. Dilemmas of the individual in public service. 30th anniversary expanded edition. New York: Russell Sage Foundation.

Mastrofski, S.D., Worden, R.E. \& Snipes, J.B. (1995). Law enforcement in a time of community policing. Criminology, 33(4), 539-563.

Maynard-Moody, S. \& Musheno, M.C. (2003). Cops, teachers, counselors: stories from the front lines of public service. Ann Arbor: University of Michigan Press.

Meyer, J.A.F. (2001). Strange science: subjective criteria in parole decisions. Journal of Crime and Justice, 24(1), 43-70.

Ministerie van Justitie (2007). De theoretische handleiding van de training voor cognitieve vaardigheden. Den Haag: Ministerie van Justitie.

Monnat, S.M. (2010). The color of welfare sanctioning: exploring the individual and contextual roles of race on TANF case closures and benefit reductions. The Sociological Quarterly, 51(4), 678-707.

Moynihan, D. \& Herd, P. (2010). Red tape and democracy: how rules affect citizenship rights. The American Review of Public Administration, 40(6), 654-670.

Riccucci, N. (2005). How management matters: street-level bureaucrats and welfare reform. Washington, DC: Georgetown University Press.

Spohn, C. (2000). Thirty years of sentencing reform: the quest for a racially neutral sentencing process. Criminal Justice, 3, 427-501.

SVG Verslavingsreclassering (2009). Leefstijltraining voor verslaafde justitiabelen. Deel A: Theoretische en managementhandleiding.

Tummers, L.L., Bekkers, V., Vink, E. \& Musheno, M. (2015). Coping during public service delivery: a conceptualization and systematic review of the literature. Journal of Public Administration Research and Theory, 25(4), 1099-1126.

Ulmer, J.T. \& Bradley, M.S. (2006). Variation in trial penalties among serious violent offenses. Criminology, 44(3), 631-670.

Ulmer, J.T. \& Johnson, B. (2004). Sentencing in context: a multilevel analysis. Criminology, 42(1), 137-178.

Wartna, B.S.J., Tollenaar, N., Blom, M., Alma, S., Essers, A.A.M. \& Bregman, I.M. (2010). Recidivebericht 1997-2007. Den Haag: WODC. 
Wenger, J.B. \& Wilkins, V.M. (2009). At the discretion of rogue agents: how automation improves women's outcomes in unemployment insurance. Journal of Public Administration Research and Theory, 19(2), 313-333.

Winfree Jr, L.T., Sellers, C.S., Ballard, V.S. \& Roberg, R.R. (1990). Responding to a legislated change in correctional practices: a quasi-experimental study of revocation hearings and parole board actions. Journal of Criminal Justice, 18(3), 195-215.

Winter, S. (2002). Explaining street-level bureaucratic behavior in social and regulatory policies. Boston, MA: APSA.

Zatz, M.S. (2000). The convergence of race, ethnicity, gender, and class on court decision making: looking toward the 21st century. Criminal Justice, 3, 503-552. 